\title{
Analysis of Fiber Orientation Influence to Dynamic Properties of Composite Structures
}

Milan Žmindák ${ }^{1}$, Zoran Pelagić ${ }^{1}$, Jozef Soukup ${ }^{2}$

${ }^{1}$ Department of Applied Mechanics, Faculty of Mechanical Engineering, University of Žilina, Univerzitná 1, 01026 , Slovak Republic, E-mail: milan.zmindak@fstroj.uniza.sk, Email: zoran.pelagic@fstroj.uniza.sk

${ }^{2}$ Jan Evangelista Purkyně University in Ústí nad Labem, Faculty of Production Technology and Management, Na Okraji 1001, 40096 Ústí nad Labem, Czech Republic

In modern analysis of structures it is not only important to study structures subjected to static loading but also to study the effects of dynamic loading. One of the results of impact loading is the dynamic response of structures. This can cause far more damage than the effects of static loading. Composite materials are more and more used in engineering praxis. This allows the creation materials of high strength at low weight which are more durable then the same construction made of homogenous materials. This paper presents a study of dynamic response of carbon fiber reinforced polymer composite plates in the form of modal analysis and transient response (subjected to unit pulse point load in the center of the plate). The plate consists of layered uniaxial carbon fiber fabric and the layers are layered symmetrically at different angles for various variants. The response in the form of displacement magnitude is measured. At the end a comparison study is presented for each analysis.

Keywords: Finite element method, Composite Materials, Carbon Fiber Reinforced Materials, Response of Structures

\section{Acknowledgement}

The authors gratefully acknowledge for support the Slovak and Technology Assistance Agency registered under number APVV-0736-12, Slovak Grant Agency VEGA 1/0983/15.

\section{References}

[1] MEYERS, M. A. (1994). Dynamic behaviour of materials, John Wiley, New York, 1994.

[2] BREPTA, R. (1997). Shock and waves in solid elastic bodies. Czech Technical University in Prague, (in Czech).

[3] MARKUŠ, Š. (1982). Vibration mechanics of cylindrical shells. VEDA 1982, Bratislava (in Slovak).

[4] TRNKA, J., MAZUCH T. (2000). Experimental and theoretical analysis of wave propagation in cylindrical shells. Engineering Mechanics, pp.277-281 (in Czech).

[5] PÕDRA, P., ANDERSSON, S. (1999). Simulating sliding wear with finite element method; Tribology International 32.

[6] KOMPIŠ, V., VANČO, M., FERENCEY, V. (2010). Shock waves in composite materials, Mechanical Engineering, pp. 73-87.

[7] ŽMINDÁK, M., RIECKY, D., PELAGIĆ, Z., DUDINSKÝ, M. (2013). Meshless Local Petrov-Galerkin Formulation for static Analysis of composite plates reinforced by Unidirectional Fibers. American Journal of Mechanical Engineering.

[8] OSTACHOVICZ, W. KUDELKA, P., KRAWCZUK, M., ZAK, A. (2012). Guided Waves in Structures for SHM: The Time-Domain Spectral Element Method. John Wiley \& Sons.

[9] FABIAN, S., SALOKYOVÁ, Š., JACKO, P. Experimental verification of the frequency spectrum of un wears and wears guidance tube on the technological head vibrations creation in the production system with AWJ technology. In Manufacturing Technology, Vol. 12, No. 13, p. 105-108

[10] MAZÚCH, T.: (2005). Semianalytical FE approach to modeling of the Cylinders flexural vibration. Building Research Journal, vol. 52.

[11] NOVÁK, P., MEŠKO, J., ŽMINDÁK, M. (2013). Finite Element Implementation of Multi-Pass Fillet Weld with Phase Changes. In Manufacturing Technology, Vol. 13, No. 1, p. 79-85

[12] JAKUBOVIČOVÁ, L. SÁGA, M., VAŠKO, M. (2013). Impact Analysis of Mutual Rotation of Roller Bearing Rings on the Process of Contact Stresses in Rolling Elements In Manufacturing Technology, Vol. 13, No. 1, p. 5054 